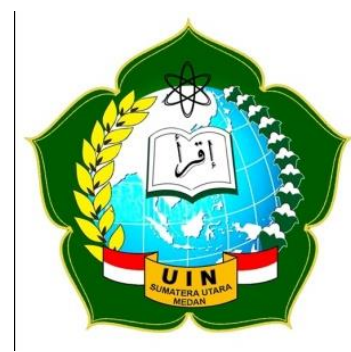

VISION JOURNAL

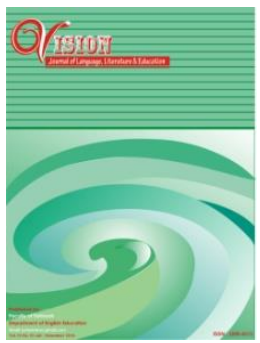

\title{
THE UTILIZATION OF ANIMATION VIDEO IN NARRATIVE TEXT WRITING CLASS: AN EXPLORATION OF STUDENTS' PERCEPTIONS
}

\author{
Misbah Hayati Siregar \\ Department of English Education, UINSU \\ Email: misbahhayati06@gmail.com
}

\begin{tabular}{|l|l|}
\hline Keywords & Abstract \\
$\begin{array}{l}\text { Keywords: Animation } \\
\text { Text, Senior High School }\end{array}$ & $\begin{array}{l}\text { The utilization of animation video as a strategy based on CALL } \\
\text { (Computer-Assisted Language Learning) approach has been } \\
\text { implemented by English language teachers, practitioners, and } \\
\text { facilitators due to its enjoyable and meaningful impacts on students' } \\
\text { learning. This present study aimed to describe the students' } \\
\text { perceptions on utilizing animation video in English writing class } \\
\text { focusing on narrative text. Qualitative research approach, } \\
\text { particularly a case study design was employed to conduct this study. } \\
\text { To collect the data, the researcher used questionnaire, interview, and } \\
\text { documentation which were analyzed with descriptive statistics and } \\
\text { Miles and Huberman theory. Twenty-eight students were recruited } \\
\text { as the participants in this study, however only three were invited to } \\
\text { the interview session which was conducted to deeper explore their } \\
\text { perceptions of the animation video utilization. The results revealed } \\
\text { that there were three main findings which tended to be positive } \\
\text { perceptions, namely: 1) enthusiasm in the use of animation video as } \\
\text { a learning media, 2) better comprehension of the story which helped } \\
\text { them to portray the concept easily, to acquire more vocabulary, to } \\
\text { organize the generic structure, and to convey the moral lesson, and } \\
\text { 3) students felt motivated to write narrative text properly. From those } \\
\text { results, this study concludes that the utilization of animation video in } \\
\text { narrative text writing class has given great contributions for the } \\
\text { students' learning. This study suggests that the use of animation } \\
\text { video be practiced in English language teaching learning process, } \\
\text { particularly in the teaching and learning of narrative text writing. }\end{array}$ \\
\hline
\end{tabular}

Faculty of Tarbiyah and Teacher Training, 1st Floor

Jalan Willem Iskandar Psr V Medan, 20731

Telp. 061- 6622925 - Fax. 061 - 6615685 


\section{INTRODUCTION}

As an international language, English plays an important role almost in all aspects of life. It becomes the world's most widely spoken language that many people use English as a mean of international communication such as in technology, art, social relation, trade, education, business and tourism (Fithriani, 2018). In education field, English takes important part because many sources of knowledge like books or journals are written in English (Nishanthi, 2018). Thus, by mastering English, people will be able to follow the development of science and education.

In Indonesia, English is taught as foreign language (EFL). Harmer explained that EFL described situations where students were learning English in order to use it with any other English speaker in the world (Harmer, 2007). Therefore, in Indonesia, English becomes the subject of study that has been taught from elementary school up to university level (Fauzi, 2019). According to Government regulation in the 2013 curriculum (Permendikbud, 2013), the goal of learning English is to develop the students' ability in order to communicate which includes the ability to listen, speak, read and write. It prepares the students to master the English basic skills, which will support their competences in oral and written communication on advanced level.

However, writing skill becomes the most complicated skill that should be mastered by students because the students should be able to express their ideas, feeling, and opinion in good written form. Fithriani (2018) also stated that EFL students thought that English writing itself has been considered as the most challenging skill. It is because they need to switch their thoughts from the first language (Indonesian) to the second language (English). That is why EFL students find it more difficult to write in English.

In senior high school level, the students are obliged to master short functional text such as descriptive text, recount text and narrative text (Zahroh, 2014). According to Anderson in Zahroh (2014), narrative is text, which tells a story and entertains or informs the reader or listener. The students are required to be able to understand and make a narrative text cohesively based on the social function and generic structure of the text. In reality, the students are still confused if they are asked to write narrative text because they only know the generic structure and language features of that kind of text.

In order to help the students' problems in writing narrative text, some the English teachers had provided innovative teaching materials that built link the young generation, school culture and technology in the school follows the content of learning (Kupiainen, 2015). 
Creative language teachers know using technology in language teaching and learning activity as innovation in nowadays. Thus, one of the famous phenomena in English classroom is the integration of technology tools.

CALL (Computer-Assisted Language Learning) is one of the most popular tools that rely on computer as a reference implementation of applications (Alkadi, 2018). However, the terminology was recently expanded to include not just the official desktop and laptop devices labeled computers but other potential technological facets used in second language. Computer is claimed to potentially influence the classroom atmosphere. It emerges as a prominent technology in promoting the development of education. In EFL teaching process, it brings new perspective for both the teacher and the students. The communicative CALL surfaced in parallel with the cognitive theories that assumed that humans are different; and based on this assumption, some students learn better by watching movies, animations, and listening to audios; and some by using images.

One of media, which integrated with CALL in writing skill, is audiovisual media. Audio visual is effective media that can be used in teaching learning process because it can be seen and be heard. One of examples of audiovisual media is animation video. This media has been used by some levels of school especially at Senior High School. The teacher chooses it as one of the learning media for their students. Thus, animation video helped students to master the materials in writing narrative text.

Vukoja (2005) stated that the use animation video in writing activity could explore the structural devices of the story (plotlines, character development, setting, and theme). It will be easier for the students in acquiring the knowledge in learning process if the teacher uses animation video. It cannot only help the students to get ideas more realistic in understanding narrative text but also in constructing ideas to create it (Tanya, 2005). As a researcher, Hastrianda (2018) stated that motion on the screen is important for attracting onlooker interest. The students can focus on the screen without losing their attention. Besides, animation can make the explanation became clearer and more understandable and could make the understanding of the process of the story also became easier.

The researcher also found the same phenomenon at the school when the researcher did the teaching practical. It was found that the English teacher used animation video as media in teaching writing narrative text. The researcher acknowledged it as one of the CALL phenomena. Therefore, the researcher intended to gain further research from the students' perspectives. 
From the previous study, it can be showed how the animation video takes part on the better process of teaching and learning activity. Many teachers have used animation video in writing narrative text, but only few researchers investigated from the students' perspectives. Thus, the researcher intended to investigate the phenomenon about the students' perceptions on the utilization of animation video in writing narrative text.

\section{LITERATURE REVIEW}

\section{Writing as a Language Skill}

Writing is one of the language skills that should be owned when learning a language. Dealing with writing, Nunan (2005) explained that writing is a tool for communication between the writer and the reader. As a result, writing must be comprehensible in order for readers to comprehend the text's meaning. In line with this, Klimova (2020) explained that writing helps to express the development of communication abilities, the creation of convincing and rational arguments, the ability to begin the contemplation of thoughts, the acquisition of reasoning skills, and the giving and accepting of input. Writing is a type of expression in which a student expresses his or her thoughts and opinions in written form.

Writing is as critical as speaking, listening and reading. It requires the students must be able to compose the writing product. There are four processes of writing which exist (Harmer: 2004) : 1) Planning, the writers have to begin with planning. The writers need a clear idea to start writing something. This process concerns three key points; intention, audience, and composition of content, 2) Drafting, a set of techniques to plan and create a sustainable document, 3) Editing, connects to revise and edit the writing product. It describes as a means of improving the draft. It is about re-examined and re-evaluated to shape the good quality of writing product, and 4) A final draft, a published one which is ready to submit to the targeted audience, accompanied by an examination. The final draft is the final product text file. It could be an article, a book, newspaper, magazine, and the other text.

1. Writing Instruction in Indonesia EFL Context

The instructional content continues to be based on the spontaneity of conversation in the classroom, which related to the implementation in Curriculum 2013 (Kemendikbud, 2014). It means that the students have to be able to communicate spontaneously. Furthermore, Ayuningtyas in Ariyanti (2016) has stated that the students must be involved in the classroom events, while the teacher acts as facilitator to guide the teaching and learning process. 
Nowadays, the teacher is encouraged to use different approaches to develop their teaching skills. In this case, the teacher must be involved in developing and delivering writing materials.

\section{Genre in EFL Writing}

Genre is used to refer to particular text-types, not to traditional varieties of literature. It is a type or kind of text, defined in terms of its social purposes, also the level of context dealing with social purpose (Hartono, 2005). Along with Brooks and Warren (1979) who stated that genre as a closed, formal system-based definition on genre and its intention but described according to form: exposition, argumentation, description, narration. Genre also means as a based accession, function, behavior, and interaction structures. There are five fundamental genres of writing, which are describing, instructing, arguing, explaining, and narrating. There are different genres of writing (Dirgayasa, 2014), namely: Narrative, News item, Description, Hortatory Exposition, Explanation, Analytical Exposition, Discussion, Spoof, Recount, Anecdote, Report, Review, and Procedure.

\section{Narrative Text}

A narrative text is a text, which tells a story. Narrative text is an imagination or a complicated event, which directs to a crisis that finds a solution at last. According to Anderson, narrative is a piece of text, tells a story and, in doing so, entertains or informs the reader or listener. (Anderson \& Anderson, 1998). Narrative is the most common of writing because the writer just tells his/her story without any purposes. Narrative places acts in times and tells what happened according to natural time sequence. Based on explanation above, it is stated that the point of narrative text is its series of events. The purpose of narrative text is to entertain, to express feelings, to relate an experience, to inform (to explain what happens and to teach a lesson), to persuade (to convince the reader).

There are many different types of narrative texts. They can be imaginary, factual or a combination of both. They may include fairy stories, mysteries, science fiction, romances, horror stories, fables, myth and legends, slice of life (Dirgayasa,2014). Here are the explanations from the kinds of narrative text:

1) Fairy stories are well-known story from folklore for children, which often involve fairies or other magical characters.

2) Mysteries are a genre of fiction usually involving a mysterious death or a crime to be solved.

3) Science fiction, a genre of fiction in which the stories often tell about science and technology of the future. 
4) Romance is a story that deals with romantic love. There are some obstacles in the way but true love usually wins out in the end.

5) Horror, a story that attempts to scare the reader or listener with frightening events but which usually ends happily. For example: Dracula.

6) Fable is a story that shows something in life or has a meaning to a word. The characters of a fable may be people, animals, and legendary creatures. Mostly, the characters of fable are animals.

7) Myth and legends are a folklore genre consisting of narratives or stories that play fundamental tales or origin myths.

8) Slice of life is a story that portrays a "cut-out" sequence of events in a character's life.

\section{Technology Integration in Language Learning}

According to Hennessy in Ahmadi (2018), technology integration is defined in terms of how teachers use technology to perform familiar activities more effectively and how this usage can re-shape these activities. Technology integration as the use of technology to improve the educational environment. It supports the classroom teaching through creating opportunities for learners to complete assignments on the computer rather than the normal pencil and paper (Ahmadi, 2018).

From that, we know technology has always been an important part of teaching and learning environment. It is an essential part of the teacher's profession which they can use it to facilitate the learning. When we talk about technology in teaching and learning, the word 'integration' is used. With technology being part of our everyday lives, it is time to rethink the idea of integrating technology and aim to embed technology into teaching to support the learning process.

\section{CALL (Computer-Assisted Language Learning)}

CALL is a term used by teachers and students to describe the use of computers as part of language learning (Gündüz, 2005). Levy (1997) describes CALL as the search and study of the use of computer applications in language learning and teaching. Chapelle (2001) defines CALL as the area of technology and teaching and learning Second Language. Meanwhile, Beatty (2003) defines CALL as any learning process that uses a computer, which results in an increase in her language skills. In addition, the materials used in CALL can be in the form of materials made specifically for language learning and materials that can adapt to computerbased material such as text, video, sound, animation etc. 
The computer network has offered modern media and tool to support the teaching and learning process, especially through writing. Through the computer network, students are able to access learning material in the form of writing texts, the learning videos, grammar, and vocabulary (Lomidazde, 2011). This network system beneficial either for the students or for teacher more easily connected to the world of information so that they can improve their knowledge. Lomidazde (2011) stated that the computer technology has given a new application for people, such as web tools, electronic journals, Blogs, Facebook, Twitter and YouTube. These kinds of application can be categories as the learning process through the Computer Assisted Language Learning (CALL) that can help students to get the references in order to improving their knowledge.

\section{Animation Video}

One of video that can be used in teaching writing is animation video. Animation video refers to series of movement of the images that contain story, have conflict, and dialogue and followed by sound. Manser (2000) said that animation video is sequences of images that provide entertainment to enact a story by sound and illusion of continuous movement. It means that animation video is connecting the story with sequence of movement of images and sound.

Animation video is a great medium in writing narrative text. This idea is supported by Barthes (2004). He said that animation video is great device that can amuse the audience with imaginary world powerful characters. Moreover, Klarer (2004) stated that animated film or video is like a novel. It has narrative technique, plot, and the change the setting and time structure. In short, it can be defined that animation video has complete structures that can amuse and entertain the audience with imaginary powerful characters. It provides setting of the story, conflicts, and characterization, which are performed on the media.

\section{METHOD}

In this study, the researcher chose a case study as the most suitable approach because this design allows the researcher to investigate and understand how and why the phenomenon occurred and formed as can be seen as a case. This research also provided in-depth into the case of students' perceptions. As a result, a case study approach allowed the researcher to study particular learning process in an attempt to understand the case of students' perception of utilizing animation video in writing class particularly narrative text.

The participants of this research were the tenth-grade students of MAS Madinatussalam, Tembung. The researcher conducted the research only in one class with 
twenty-eight students in total. In a qualitative research, source of primary data is the actions and the words, and additional data like the written data, document, picture, or statistical data. Therefore, the researcher obtained the data by using questionnaires, interview, and documentation.

\section{FINDING AND DISCUSSION}

By using color-code, the researcher presented the results through classifying the same statements in coloring the same perceptions. Thus, the results showed that the students perceived some positive perceptions on the utilization of animation video in writing narrative text which includes i) Enthusiasm in the use of animation video as a leaning media ii) Better Comprehension of the Story and iii) Students felt motivated to write narrative story properly, that can be seen in the following section.

\section{A. The Students' Perceptions on the Utilization of Animation Video in Writing Narrative Text}

\section{Enthusiasm in the Use of Animation Video as a Learning Media}

The first perception is gotten by identifying the statements in questionnaire which indicated the happy feelings that students feel about the utilization of animation video. Three statements reveal the result about the students' enthusiastic in utilizing animation video that can be seen in the following chart:

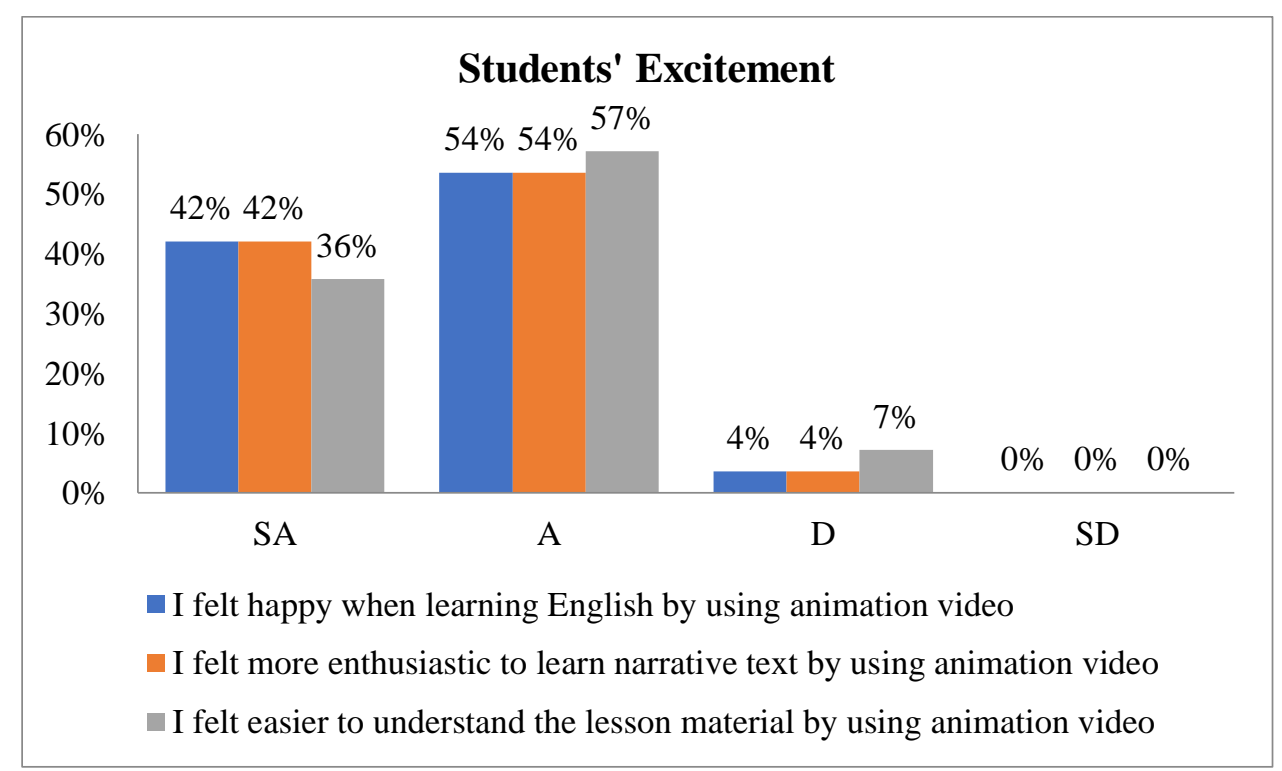

Figure 1 The total count of students showing their happy feelings

Based on Figure above, the result reveals from the three statements above; the students feel happy when learning English by using animation video (blue) reach $42 \%$ for Strongly Agree, 54\% for Agree, $4 \%$ for Disagree, and 0\% for Strongly Disagree. The students feel more 
enthusiastic (red) reach $42 \%$ for Strongly Agree, 54\% for Agree, $4 \%$ for Disagree, and $0 \%$ for Strongly Disagree. The, the students feel easier to understand the lesson material (green) reach 36\% for Strongly Agree, 57\% for Agree, 7\% for Disagree, and 0\% for Strongly Disagree.

From those findings, it can be said that the students are excited when watching animation video for learning to write recount text. Animation video is known as an audiovisual media that can be heard and be seen by the students and it can make students interest to watch. It is combined with a picture movement and displayed an interesting dynamic visual such as cartoon video and fable. In addition, the students felt excited because it was very first time for them in terms of learning English lesson by using media particularly animation video.

\section{Better Comprehension of the Story}

a. Animation Video Helped the Students to Portray the Concept of the Story

\section{Easily}

The students agree that they easily could portray the concept of the story after watching animation video. For more detailed information, it can be seen in the following chart:

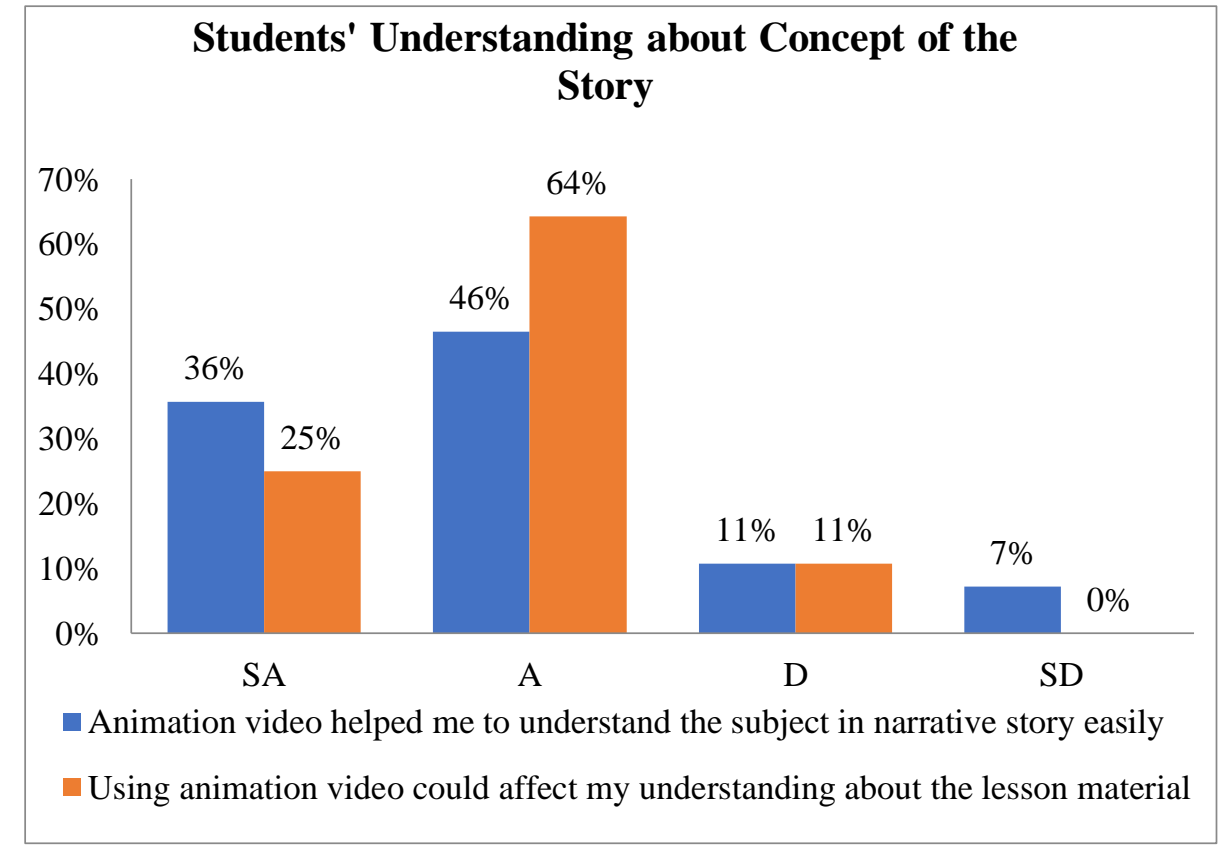

Figure 2 The total count of students showing their understanding of the story

Based on Figure above, the result reveals from the two statements above; the animation video helps the students to understand the subject in narrative story easily (blue) which reach 36\% for Strongly Agree, 46\% for Agree, 11\% for Disagree, and 7\% for Strongly Disagree. Then, using animation video could affect students' understanding (red) which reach $25 \%$ for Strongly Agree, 64\% for Agree, 11\% for Disagree, and 0\% for Strongly Disagree. From the 
statement above, it indicates that by watching animation video, most of the students agreed that it helps them to portray the concept of the story easily.

\section{b. Animation Video Helped the Students to Require More Vocabulary Easily}

In case of vocabulary development, they state that by watching animation video has been giving them access to look at the things, places, and objects in real visualization. As state by Student 1 and Student 2 that can be seen in the following:

Student 1: "I think it made me easier to get the point. Because of the narrative story which was presented had many vocabularies, it has increased my vocabulary as well."

Student 2:" From the textbook it is hard for me to memorize the vocabulary, but when using animation video, I could read the subtitle and I could hear it so it really helped me out."

As many vocabularies require by the students, the students feel comfortable to rewrite the narrative story which can be seen as follows:

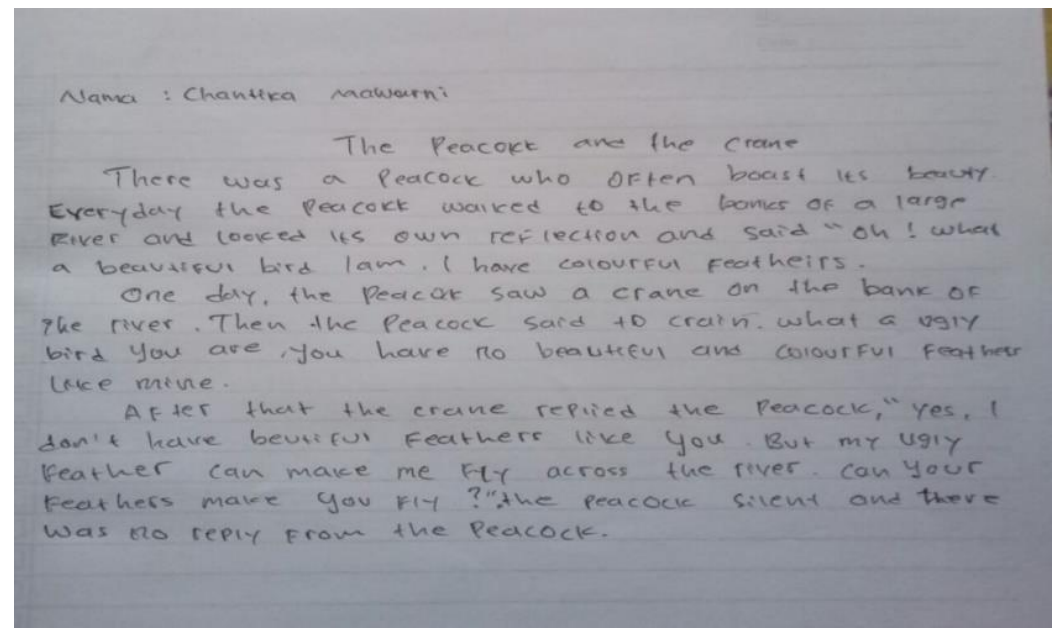

Figure 3 Student's Writing Product

\section{c. Animation Video Helped the Students to Organize the Generic Structure Easily}

The result reveals that most of students have positive perception. They state that by using animation video, they could write the text systematically as requiring generic structure in narrative text. Furthermore, the students also state more which could be seen in the following:

Student 1: "What can I say, it was easier to follow the storyline like how to introduce the story, what was the problem, and what the conclusion." 
Student 2: "It helped me out, because I could understand the generic structure of the story like from the beginning to the end, and I could re-write it when I got an assignment to write again the story."

Based on the Student 1 and Student 2 statements, it shows that the students could understand the generic structure of narrative text. It makes them more aware to write the narrative text systematically and correctly by watching animation video. In addition, it helps them out in producing good narrative text since they understood some text elements in narrative text. Besides, by watching animation video, it helps the students to comprehend the detail information about what had already happened in the story.

\section{d. Animation Video Helped the Students to Convey Moral Lesson Easily}

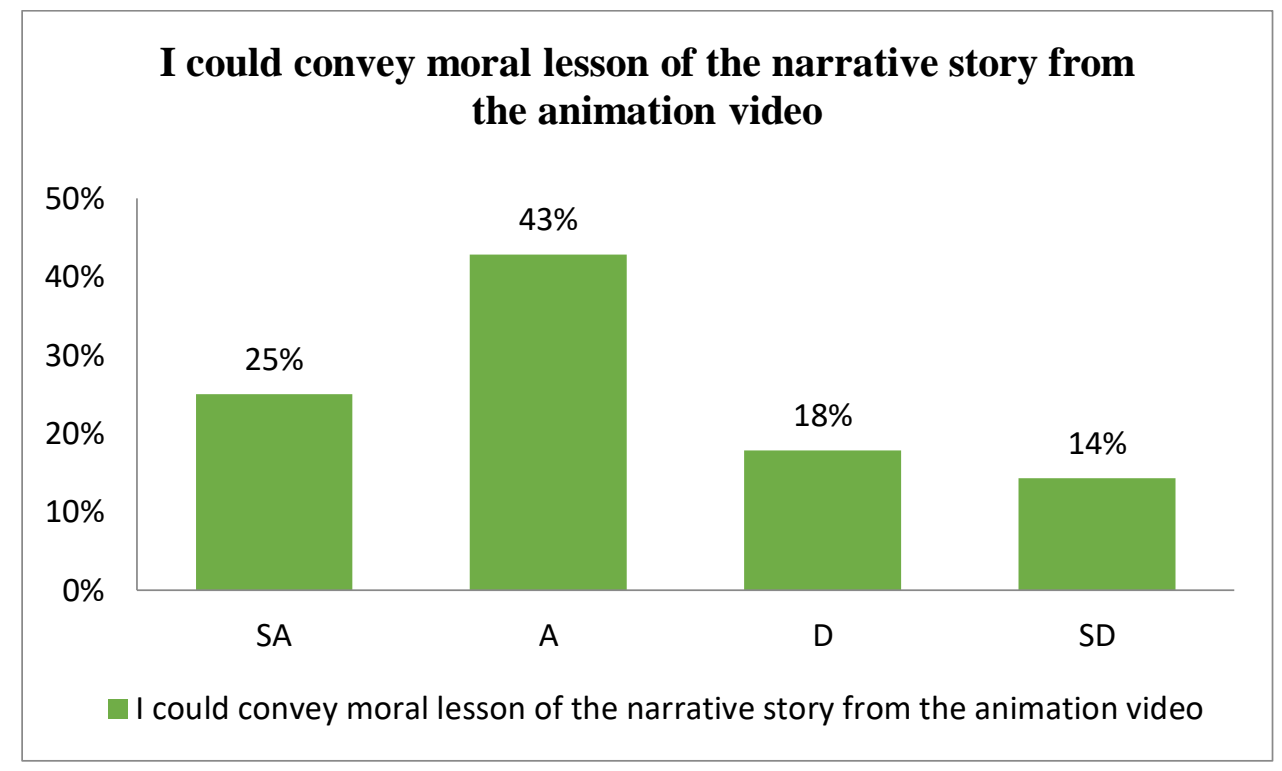

Figure 4 The total count of students showing their understanding in conveying the moral lesson of narrative story

Based on Figure above, the results show that most of the students could convey moral lesson of the narrative story from the animation video (green) which reach $25 \%$ for Strongly Agree, $43 \%$ for Agree, $18 \%$ for Disagree, $14 \%$ for Strongly Disagree. It can be said that most of the students agree that by watching animation video helps them in understanding the moral lesson easily. Thus, the aim of learning narrative text is to get the message of the story, which could give valuable advice for the students. 


\section{Students Felt Motivated to Write Narrative Text Properly}

The third perception is gotten by identifying the statements in questionnaire which indicates positive thoughts about the utilization of animation video in writing narrative text. For more detailed information, it can be seen in the following chart:

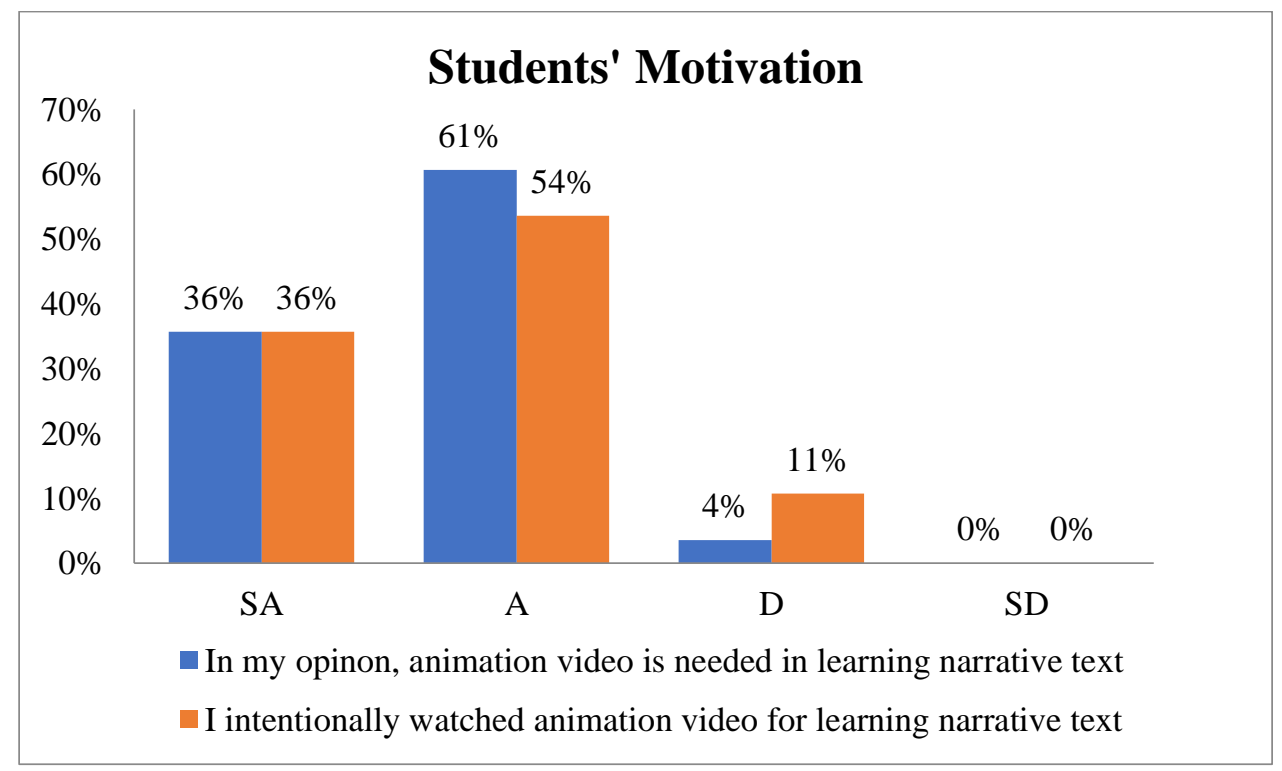

Figure 5 The total count of students showing their motivation towards the utilization of animation video

Based on Figure 4.10, the result revealed from the two statements above; the students think that animation video is needed in learning narrative text (blue) which reach $36 \%$ for Strongly Agree, 61\% for Agree, 4\% for Disagree, and 0\% for Strongly Disagree. Furthermore, the students intentionally want to watch animation video for learning narrative text (red) which reach 36\% for Strongly Agree, 54\% for Agree, 11\% for Disagree, and 0\% for Strongly Disagree.

From the results above, it could be said that most of the students agree that animation video increases their motivation to learn. These responses come up because animation video is unique and different from the previous media that has been taught by the teacher.

\section{CONCLUSION}

Based on the results, it can be concluded that the utilization of animation video in writing narrative text has given great contributions for them. Therefore, there were some perceptions in terms of positive perceptions that perceived by the students on the utilization of animation video in writing narrative text which divided into three main themes such as 1) Enthusiasm in the Use of Animation Video as a Learning Media, 2) Better comprehension of 
the story in terms of the animation video help them to portray the concept easily, to require more vocabulary, to organize the generic structure, and to convey moral lesson, and 3) Students felt motivated to write narrative text properly.

\section{REFERENCE}

Ahmadi, D., \& Reza, M. (2018). The use of technology in English language learning: A literature review. International Journal of Research in English Education, 3(2), 115125.

Alkadi, A. (2018). A review of technology integration in ELT: From CALL to MALL. Language Learning and Educational Research, 1(1), 1-12.

Ariyanti. (2016). The teaching of EFL writing in Indonesia. Journal of Dinamika Ilmu, 16(2), 263-277.

Beatty, K. (2003). Teaching and researching computer-assisted language learning. New York: Longman.

Depdiknas. (2013). Standar kompentensi kurikulum k13. Jakarta: Departemen Pendidikan Nasional.

Dirgeyasa, Wy. I. (2014). Academic writing: A genre-based approach. Medan: Unimed Press.

Fauzi, M. I. (2019). Students' perception on using students' worksheet (lks) in learning English. The State Islamic Institute of Surakarta (thesis).

Fithriani, R. (2018). Discrimination behind Nest and Nnest dichotomy in ELT professionalism. KnE Social Science \& Humanities, 3(4), 741-755.

Gündüz, N. (2005). Computer assisted language learning. Journal of Language and Linguistic Studies, 1(2), 193-214.

Harmer, J. (2004). How to teach writing. London: Pearson Education Limited.

Hastrianda, H. R. I. (2018). Students' perceptions on the use of videos in learning narrative text. University of Sanata Dharma of Yogyakarta (thesis).

Klarer, M. (2004). An introduction to literacy studies. New York: Routledge. Taylor and Francis Group.

Klimova, B. (2012). The importance of writing. Indian Journal of Research, 2(1), 9-11.

Levy, M. (1997). CALL: Context and conceptualization. Oxford: Oxford University Press.

Manser, H. M. (2000). Oxford learner' pocket dictionary. New York: Oxford University Press.

Nishanthi, R. (2018). The importance of learning English in today world. International Journal of Trend in Scientific Research and Development, 3(1), 871-874.

Nunan, D. (2005). Practical english language teaching (1 st edition). New York: McGraw Hill. 